\title{
Favorable legal environment as a condition for the realization of criminal procedural rights and the proper performance of criminal procedural duties
}

Entorno legal favorable como condición para la realización de los derechos procesales penales y el cumplimiento adecuado de los deberes procesales penales

\author{
Evgeniy Petuchov ${ }^{1}$ \\ Altai State University - Russia \\ petuchove@mail.ru \\ Mariya Neymark ${ }^{2}$ \\ Altai State University - Russia \\ neymark.m@mail.ru \\ Nina Dudko ${ }^{3}$ \\ Altai State University - Russia \\ dudkona@yandex.ru
}

\begin{abstract}
The article investigates the problem of legal support of the participants of criminal proceedings for the implementation of the rights granted to them by the legislator and the proper performance of their criminal procedural duties. Obstacles to the implementation of criminal procedure rights and obligations of normative (gaps, conflicts of legislation) and organizational (illegal actions of subjects, their inaction) nature are identified. The existing views of scientific researchers on the correlation of rights and obligations in the sphere of criminal justice as paired legal categories are studied and analyzed. We analyzed the provisions of the current criminal procedure legislation in Russia from presence/absence of legal conditions ensuring realization of rights and performance of duties by the participants of the criminal process.
\end{abstract}

Keywords: Favorable legal environment, rights and obligations of participants, criminal proceedings.

\section{RESUMEN}

El artículo investiga el problema del apoyo legal de los participantes en los procesos penales para la implementación de los derechos que les otorga el legislador y el cumplimiento adecuado de sus deberes procesales penales. Se identifican los obstáculos a la implementación de los derechos y obligaciones de procedimiento penal de naturaleza normativa (brechas, conflictos de legislación) y organizacionales (acciones ilegales de los sujetos, su inacción). Se estudian y analizan las opiniones existentes de los investigadores científicos sobre la correlación de derechos y obligaciones en el ámbito de la justicia penal como categorías jurídicas emparejadas. Analizamos las disposiciones de la legislación procesal penal vigente en Rusia por la presencia / ausencia de condiciones legales que garanticen la realización de los derechos y el cumplimiento de los deberes por parte de los participantes del proceso penal.

Palabras clave: entorno legal favorable, derechos y obligaciones de los participantes, procesos penales. 


\section{INTRODUCTION}

In the science of criminal procedure and among practitioners engaged in criminal proceedings, there is a common view of the norms of criminal procedure law as a source of criminal procedure rights and obligations of participants in criminal procedure activities. That is, the content of the norm of criminal procedure law is considered as a rule of possible or proper behavior of participants of criminal proceedings.

At the same time, in order to properly apply the criminal procedure norms in the course of criminal proceedings in a criminal case it is necessary to clearly understand the way of their impact on the participants of the given proceedings.

It is generally accepted to subdivide criminal procedure norms by the method of legal regulation into three types.

Administrative norms in which the legislator determines the possible behavior of participants in criminal proceedings, giving them procedural rights (in particular, the victim - the right to have a representative (paragraph 8 of Part 2 of Art. 42 of the Criminal Code (CC) of Russia), the accused - the right to bring complaints about actions (inaction) and decisions of the inquirer, the head of the department of inquiry, the head of the body of inquiry, the body of inquiry, the investigator, the prosecutor and the court and to participate in their consideration by the court (paragraph 14 of Part 2 of Art. 47 of the CC of Russia). Participants may exercise (or not exercise) these rights at their own discretion. Here, the method of regulating the behavior of participants in criminal proceedings is permission.

Obligatory norms that determine the proper conduct of participants in criminal proceedings. Such norms are characterized by a mandatory method of regulation, by virtue of which participants do not have the right to choose their behavior, and must certainly obey the prescription of the law. For example, an investigator who has detained a suspect who is a lawyer is obliged to notify the Chamber of Advocates of the Russian Federation, of which the suspect is a member, within 12 hours (part 1, clause 2.2 of part 2 of article 96 of the CC of Russia).

Prohibiting norms, which contain requirements to refrain from performing any actions (mentioned in the norm) for a participant in criminal proceedings. Such norms, as in the case with binding norms, apply a mandatory method of regulating the behavior of a particular participant in criminal proceedings by using the following terms:

- Has no right" (for example, a person may not disclose the data of a preliminary investigation which he or she has become aware of in connection with his or her participation in the criminal proceedings as an interpreter, if he or she has been warned in advance in accordance with the procedure established by Article 161 of the CC of Russia (Article 59.4.2 of the CC of Russia);

- Prohibited" (for example, in the course of criminal proceedings it is prohibited to carry out actions and take decisions humiliating the party to the criminal proceedings, as well as to treat them in a manner that humiliates their human dignity or endangers their life and health (article 9, part 1, of the Code of Criminal Procedure);

- "Inadmissible", etc.

Despite the rather large amount of accumulated theoretical knowledge in the field of interpretation of criminal procedure terms, categories, institutions (Proshlyakov, Akhmatov, 2018) and scrupulous normative regulation of the behavior of participants in criminal proceedings, law enforcement practice unfortunately demonstrates a large number of difficulties arising in the use, execution, observance and application of criminal procedure norms.

These difficulties in legal science have been suggested as obstacles. Perhaps, A.V. Malko, a scholarly legal theorist, made the most significant attempt in this matter. In particular, he developed a theory of obstacles related to the optimization of legal stimulation and legal limitation, with the identification of the most typical and harmful to the legal organization of public relations and their concept, classification by various manifestations in the legal system of modern society.

At the same time, he proposed three groups of classifications of these obstacles: 1) manageable and not manageable; 2) absence of a required legal norm or a decisive legal fact and offence resulting from "shadow management"; 3) illegal incentives and illegal restrictions (Malko, 1994).

In the development of this problem other researchers from different branches of law also supported it. In particular, attention should be paid to the work of Sandra Lyngdorf and Harmen van der Wilt, which is devoted to useful guidelines for assessing "unwillingness" and "inability" in the context of the principle of complementarity to implement procedural obligations under the European Convention on Human Rights (Lyngdorf, van der Wilt, 2009).

As well as the Russian representative of the science of civil law and civil process Vavilin E.V. (Vavilin, 2009), proposed a classification of obstacles acceptable for our study, dividing them into formal and factual ones.

The first include obstacles related to the limits of the implementation of rights, certain legislative acts containing prohibitive and binding norms, as well as related to the imperfection of the formal level of the legal system (gaps, conflicts, "inconsistencies" that have lost the relevance of the prescription in the current legislation).

The second group of obstacles includes organizational obstacles directly related to the process of implementation of rights (shortcomings in law enforcement, illegal actions of citizens and state bodies, their inaction, conflict of legitimate interests of the parties, as well as insufficient material security of legal activities). 
The significance of the given knowledge of the theory of obstacles makes it possible to reveal specific difficulties (type of obstacles) in the realization of rights and performance of obligations by subjects of legal relations and to establish "weak points" of the current legislation at the present stage of development of the legal system of Russia.

The subject of our research to a greater extent covers the obstacles of a formal nature, i.e. normative (covering the provisions of the criminal procedure legislation).

Formal or normative obstacles (errors or failures of the legislator in the form of gaps, conflicts, outdated provisions) should be established and eliminated, thus ensuring the unimpeded and full implementation of rights and the possibility of proper performance of duties by participants in criminal proceedings. Since this legislative activity is connected with human (legislator's) activity, its defects are undoubtedly subject to influence, so they should be identified and corrected. It is necessary to correct in such a way as to achieve such a law-applicable result when the corresponding conditions in the form of norms fixed in the criminal procedure legislation will effectively ensure the realization of rights and performance of duties in the sphere of criminal proceedings. In our understanding, the legislator should create such a legal environment for the participants of criminal proceedings, which would allow him/her to motivate him/her to use his/her rights and properly perform his/her duties in order to achieve personal or public interest.

Of course, the legal environment is only one of the many systems that are covered by the general concept of the environment - the environment of human habitation.

The encyclopedia of environmental sciences defines the environment as "the totality of all external conditions and influences affecting the life and development of the organism" (Platt, 1971), but the definition of "human environment" should go further. The human environment is more than external, since the internal and external are relative concepts, and the individual is an important component of his or her own environment. Thus, the human environment is a set of all conditions and influences that influence the behavior and development of a person as a person and society. "Conditions and infusions" change in time and space and, although often separated, are perceived and perceived by each person or society in different ways (Saarinen, 1969).

Taking into account the diversity of levels of organization of being, our world consists of a large number of environments, not one. Of course, one of such environments is the "biosphere" - the global environment. Nevertheless, there are many other environments that are as problematic, perhaps more understandable and easily treatable, and much closer to the individual than the global environment

Note that everything in the world is interconnected and therefore each environment is a system that overlaps, influences and is influenced by other systems. They resemble ecosystems (or at least are significant parts of ecosystems) in the sense that they are units of space where biotic and physical components and processes interact with each other to create models of energy and material flows and cycles. In the human environment, these components and processes, called scientific structures and functions (Odum, 1962), are not limited to those that originate from "nature". Indeed, they include social, economic and political (Smith, 1972) or cultural (Boyden, 1976).

The environment related to human activity can be the most diverse: school, university, industrial, etc. That is to say, to correspond to the space and activities that are carried out in this space. In our case, we connected our research with the right-wing space, in particular with the sphere of criminal procedure activity.

Our task is to develop and offer a theoretical model of such a legal environment, which allows a person (a rightwing subject) to achieve personal and public interests without hindrance by implementing rights and performing duties. In our case, in particular, in the sphere of criminal proceedings.

Of course, we are not the first in solving this problem. Therefore, it is fair to say that there are specific recommendations regarding the implementation of rights. For example, Ioanna Tourkochoriti has devoted her research to the problem of how best to exercise rights (Tourkochoriti, 2019).

Aim. Assessment of the current in Russia criminal procedure legislation and positions existing in legal science, concerning the efficiency of regulation of relations in the sphere of criminal process and setting the conditions ensuring the realization of rights and proper performance of obligations by participants of criminal proceedings.

Tasks. To analyze the current state of the norms of the acting criminal procedure legislation from the position of existence, the conditions fixed in it, providing the unimpeded realization of rights by the participants of the criminal proceedings and the opportunity to properly perform their duties. To study the existing views of legal scholars on the relationship between rights and obligations in the sphere of criminal proceedings. To formulate a proposal on a conceptual approach to the legal environment, which would be a guarantor of the efficiency of the use of rights and performance of duties by participants of criminal procedural relations. 


\section{DEVELOPMENT}

\section{Methods}

In the course of work on the article, the authors reviewed the information, summarized and evaluated the literature on the subject of the study. The results of earlier conducted researches on the problems of formation of the legal environment, mechanism of protection of the rights of a person in criminal proceedings, correlation of the criminal procedure rights and obligations of participants of criminal procedure activity, and also a problem of maintenance of their realization, proper execution and existing or arising obstacles of their realization during criminal proceedings are analyzed.

The most significant of them are: doctoral dissertations by O.I. Andreeva, B.Y. Gavrilov, E.V. Vavilin, L.M. Volodina; candidate dissertation by I.V. Kutazova; other scientific works and analytical documents of Russian and foreign scientists and law-enforcers on the subject under study have also been studied.

International legal acts (the Universal Declaration of Human Rights, the International Covenant on Civil and Political Rights, the Convention for the Protection of Human Rights and Fundamental Freedoms of November 4, 1950 and others) and normative-legal acts of national (Russian) legislation (the Constitution of the Russian Federation, the Criminal Procedural Code of the Russian Federation and others) have been subjected to critical analysis from the position of guaranteeing the realization of rights and proper performance of duties by participants of criminal proceedings.

In the course of the research, general scientific methods were used: analysis, synthesis, comparison, generalization, abstraction, induction, deduction, and system-structural methods.

Along with the general scientific methods were applied: the formal-legal method, consisting in the frontal study of the legislation governing the procedural status of participants in criminal proceedings, which allowed to study the provisions of international instruments and Russian legislation. The comparative legal method of research allowed to carry out a comparative analysis of these legal documents; the method of law interpretation, which allows to deepen and expand the results of the application of the formal legal method, to identify both literal and systemic meaning of legal prescriptions and to make a general picture of the aspects and parties of legal regulation of the behavior of participants in criminal proceedings in the exercise of their rights and performance of their duties.

Sociological methods were used to collect empirical material and substantiate the findings of the study.

\section{Results and discussion}

Investigating the legal category stated in the title of the article, E.V. Vavilin comes to the conclusion that one of the terms, which are increasingly used in the works, both by law theorists and representatives of branch legal sciences, is the legal environment (Vavylin, 2009). Indeed, the existing works devoted to the issues mentioned by us testify to the fact that their authors approach the analysis and resolution of legal problems from the point of view of their occurrence and possible resolution either in the legal environment or through its formation, optimization and development (Bochkov et al., 2007; Vavilin, 2009; Zhiltsov et al., 2013; Mochalov, 2012; Sigalov, 2008).

In legal science, there is a reasonable question, what is it about, what is this image, called "legal environment", and whether it corresponds to the phenomenon existing in real life?

The study of the problem gives grounds to believe that the legal environment exists.

That is, it is real, like many other state-legal phenomena, the existence of which is not in doubt. This begs a legitimate question: what is it? As most researchers note, the search for an answer to this question leads to a conclusion about the variability of approaches to the definition of the legal environment.

The search for our answer will begin with the following reasoning.

What is a criminal procedure is an activity that exists through the relations that arise between the participants of a criminal case. The purpose of this criminal procedure is to protect these participants of the criminal case (and all of them, including from the state). It means that this social and legal phenomenon is centered on the individual. The personality of all participants in a criminal case. Ideally, in a rule-of-law state all persons should be equal in everything, and Russia - we believe, the rule-of-law state, therefore, persons in one of its spheres under the name of criminal justice should also be equal. Hence, as it is fixed in the criminal procedure legislation of the Russian Federation, as a beginning - the principle, the dominant feature of all this criminal proceedings should be the equality of these persons, called the participants of the criminal process.

Equality of one person in relation to another in criminal proceedings is certainly ensured by their legal status. This status is known to all to be based on rights and obligations. In this case, the rights ensure the possible behavior of the individual, and the duties - due behavior (normative).

It should be noted that the behavior of any subject in the sphere of criminal court proceedings, through his attitude to the use of his procedural rights and performance of duties depends primarily on the completeness and quality of legislative regulation of his and other participants of the criminal procedural status. 
The completeness, clarity, and concentration of the fixation of rights and obligations have been mentioned and spoken about throughout the entire territory of Russia by practically all authors who study this topic (it is enough to recall only doctoral dissertations by L.M. Volodina, B.Y. Gavrilov, O.I. Andreeva and many others) (Volodina, 2003; Gavrilov, 2004; Andreeva, 2007).

Hence, we believe that the law given to the subject of criminal process and the duties imposed on him/her should cover all directions of criminal procedure activity affecting his/her moral-legal and procedural interests, and thus they should provide him/her with their effective achievement.

In this regard, it is true that Karl Marx, who was not deservedly forgotten and famous in his time, said: "There are no rights without duties, duties without rights".

In our opinion, this is the formula of a favorable legal environment for the enforcement of rights and performance of duties by participants of criminal proceedings. In order for the subject to exercise his or her rights, as well as those of other subjects, he or she should have obligations, the performance of which will lead to the creation of a favourable environment, i.e. to conditions ensuring the possibility of the realization of rights (for example, in order for the victim to exercise the right to judicial protection, he or she should fulfil the obligation to appear at the call of the investigation bodies for questioning). Conversely, the performance of duties by the subject is ensured by the presence of rights of this and other participants in the criminal process (for example, in order to fulfill the obligation of proper behavior by the person suspected (accused) - the investigating body must have and exercise the right to apply a preventive measure to such a subject, etc.).

The well-known philosopher Ilyin I.A. wrote in his work devoted to legal consciousness, that people who do not know their duties are not able to observe them; people who do not know their powers (we are talking about state officials), arbitrarily exceed them or cowardly yield to force; people who do not want to recognize prohibitions, easily forget any restraint and discipline or are doomed to legal insanity.

We see the picture where rights and obligations are guarantees for each other.

We believe that reasoning about the unilateral existence of criminal procedural rights or criminal procedural duties is not worthwhile. As a confirmation of their paired nature, we can cite the position of John H. Knox, who in his work on the Horizontal Law on Human Rights concludes that human rights are traditionally viewed as vertical, establishing rights for individuals and obligations for states. At the same time, he criticizes the proposals, which aim at a horizontal reorientation of human rights law, imposing obligations directly on corporations and other private actors. We support his position that these proposals do not take into account the horizontal implications of existing human rights law and risk undermining its structure and opening the door to new human rights restrictions (Knox, 2008).

The concept of a favorable legal environment was, as it should have been, proposed and developed by law theorists, in particular, it is enough to remember the works of N.N. Chernogor and S.N. Khorunzhiy (Chernogor, 2014; Khorunzhiy, 2014). In the sphere of civil law, this category was developed by E.V. Vavilin in his doctoral thesis "Mechanism of implementation of civil rights and performance of duties".

All of them come to a single conclusion that:

1. The most important element of the legal environment is a person and his or her social and legal activity aimed at perception, implementation and reproduction of legal provisions. It has a direct impact on the choice of lawful ways of activity regulated by the norms of law of social relations by the participants.

2. The legal environment is created by active and passive behavior of people in the public-legal sphere of society's life. It integrates the processes of establishment and development of legal relations in time and space.

We agree with the above position, where the individual is at the center, and we believe that in criminal proceedings it also finds its existence by means of, as mentioned above, fixing the equality of participants in criminal proceedings, which is based on their rights and obligations, which ensures their active, positive behavior.

Unfortunately, such a program of behavior of the participants of the criminal process, and thus a favorable legal environment in the current criminal procedure legislation has not yet been fully provided for by the legislator, has not yet been fixed.

We will show it on the analysis of the provisions of the current criminal procedure legislation of the Russian Federation (hereinafter referred to as the CPC of the Russian Federation).

Thus, in accordance with the provision of Article 258 of the CPC of the Russian Federation, the court has the right to impose liability on the participants of the court hearing (for example, as a victim, civil plaintiff, defendant) for violations of order in this court hearing. At the same time, the court is obliged to explain to them their "rights and responsibilities", and there is no such obligation in the legislation (see: Article 268 of the CCrimP of Russia). It turns out that the actions of the court are groundless as to the right to accept responsibility to these subjects, as they were not aware of the obligation to behave properly in the court session. That is, the court does not have a 
legally fixed condition for the exercise of its right! Without conscious violation of the duty, responsibility does not come and responsibility.

Further, the right of the person in respect of whom the criminal prosecution is carried out and his lawyer-defender to participate in the evidence is significantly limited (they can not fully influence the formation of evidence), as the investigation bodies have no obligation to allow them to participate in the production of all investigative actions.

As we have previously stated, the dominant principle of the criminal process today should be the principle of adversarial proceedings, during the implementation of which, of course, the equality of the parties should be respected, as we understand it, and with regard to the implementation of the equal right of the parties to carry out investigative actions and participate in them, regardless of whose initiative they are carried out, of the bodies in the proceedings of which the criminal case is pending or at the request of the lawyer-defender and his client.

It follows from this that there should be no restrictions on the participation of a lawyer-defender in the investigation activities in case of application of part 3 of article 11 of the Criminal Procedural Code of the Russian Federation, and, accordingly, the investigation bodies are obliged to allow the lawyer-defender and provide him with the opportunity to participate in such investigation activities. If the investigation bodies are concerned about keeping the information of the preliminary investigation secret, the guarantee of non-disclosure of such information is the responsibility of the defense lawyer in the order of application to him/her of part 3 Article 161 of the CPC of Russia. At the same time, they can use the mechanism of implementation of this procedure, which was developed in his dissertation prepared under the guidance of the author of this article I.V. Kutazova (Kutazova, 2011).

Let us give another rather recent example confirming that the right of one subject of criminal proceedings can be exercised only if it corresponds to the duty of another, which should be properly executed. Thus, part 3.1 of Article 46 of the Criminal Procedural Code of the Russian Federation enshrines the following provision: from the moment a preventive measure in the form of detention or house arrest is chosen, a suspect may have (read - has the right to) visits with a notary without limitation of their number and duration in order to certify the power of attorney for the right to represent the interests of the suspect in the sphere of entrepreneurial activity. At the same time, it shall be prohibited to perform notarial actions in respect of property, funds and other valuables that may be arrested in cases stipulated by the present Code.

We consider that at understanding of sense of the given norm becomes obvious that the legislator here provides the duty of bodies of investigation, the court consisting in obligatory establishment and definition by the given subjects of property, money resources and other values on which arrest can be imposed. In addition, their subsequent obligation is logically to inform the suspect of the property and to warn him or her not to alienate it. We believe that this person is not a seer himself and, accordingly, cannot foresee what the investigating authorities or the court intend to do with his property, money and other valuables.

There are still many examples in this respect. However, being limited by the scope of the scientific article, we believe that this is enough to make sure that our ideas are correct.

Undoubtedly, our beliefs about the normative component, which fixes the basis of a favorable legal environment, are also based on the provisions of international legal acts (Convention, 1950; International, 1996; Universal, 1948), which are recognized by the entire legal world community (the Convention on the Protection of Human Rights and Fundamental Freedoms of November 4, 1950; the International Covenant on Civil and Political Rights; the Universal Declaration of Human Rights), the Constitution of the Russian Federation, and the industry-specific criminal procedure legislation, which already contain fundamental recognition of the existence of this environment.

If we take the national legislation, it is, first of all, a constitutional level where there are guarantees for the realization of fundamental natural and inalienable human rights and freedoms (Articles 20-29 of the Constitution of the Russian Federation).

At the branch criminal procedure level, the legislator has formed the most essential guarantees of the existence of a favorable legal environment as a condition to ensure the proper performance of duties by participants in criminal procedure activities in the provisions defining responsibility. Here we mean application of measures of compulsory execution of norms in which obligations of participants of criminal proceedings are fixed, in particular:

- Through the use of preventive coercive measures (e.g., an additional connoisseur, investigator, as well as the court, within the limits of their powers, have the right to choose one of the preventive measures provided for by the Criminal Procedural Code of the Russian Federation, if there are sufficient grounds to believe that the accused or suspect: 1) will escape from the inquiry, preliminary investigation, or trial; 2) may continue to engage in criminal activities; 3) may threaten a witness, other participants in the criminal judicial proceedings, destroy evidence, or otherwise prevent (Part 1, Article 97 of the CC of Russia);

- Through the use of legal remedial measures (for example, if the prosecutor finds the decision to institute criminal proceedings against the investigator to be unlawful or unjustified, he may, within 24 hours of receiving the materials on which the criminal case was based, cancel the decision to institute criminal proceedings and issue a reasoned decision, a copy of which may be immediately sent to the official who initiated the criminal proceedings 
(part 4 of Article 146 of the CC of Russia);

- By means of penalties (for example, in cases of non-fulfillment by the participants of the criminal proceedings of the procedural duties provided for by the Criminal Procedural Code of the Russian Federation, as well as violation by them of the order in court proceedings, they may be imposed a monetary penalty by the court in the amount of up to two thousand five hundred rubles (Art. 117 of the Criminal Procedural Code).

In addition, the failure (improper performance) of the duties imposed by the legislator in the criminal procedure law on persons conducting the proceedings in the case may entail liability for disciplinary (for example, the imposition of disciplinary responsibility on the person conducting the inquiry) or criminal (for example, for knowingly giving a false conclusion by the expert is responsible in accordance with Article 307 of the Criminal Code of the Russian Federation).

However, as we have shown above the possibilities of legislative support of formation of the favorable legal environment guaranteeing the realization of rights and proper execution of obligations in the sphere of criminal shipbuilding are far from being exhausted. Imperfection of criminal procedure regulation in the analyzed issue requires further research of the problem of rights and obligations of participants in criminal proceedings in order to make appropriate adjustments to the current legislation on criminal procedure.

\section{CONCLUSIONS}

Thus, defining the importance of the existence of a favorable legal environment in the field of criminal proceedings, taking into account our arguments and based on existing knowledge of the essence of the legal environment, we formulate its concept. Favorable legal environment in the sphere of criminal proceedings is a balanced system of criminal procedure rights and obligations, provided with sufficient organizational and legal means (tools), fixed in the procedural legislation, creating the necessary conditions and opportunities to achieve personal and public interests of the participants of criminal proceedings.

In the end of the reasoning about necessity of creation of the favorable legal environment in criminal proceedings, it would be desirable to result the wise words expressed by the people in the form of a toast about a small bird which had desire to reach the sun. Realizing her desire, she rose higher and higher to the sun, but unfortunately, could not embody her own lanes, as burned the wings and fell to the depths of the blue sea. The moral of this folk wisdom is that our desires always coincide with our capabilities.

In view of this morality, in criminal proceedings, it would be desirable for the legislation governing it to inspire the participants to exercise the rights granted to them and to properly discharge the duties entrusted to them. In doing so, the legislation would provide the conditions that would create a real opportunity to exercise these rights and duties in accordance with the interests (needs) inherent in each participant in the criminal process, and not by coercion of others.

Hence, apart from the existing state coercion, we believe it is possible to enshrine in the criminal procedure legislation the incentives that encourage participants of the criminal process to properly perform their duties, the development of which we take upon ourselves the obligation to engage in further.

The formulated proposals on perfection of the legal basis providing realization of the rights and proper execution of duties in the sphere of criminal proceedings can be used in both normative activity of legislative bodies and law enforcement activity of law-enforcement bodies of the state. 


\section{BIBLIOGRAPHIC REFERENCES}

Andreeva, O.I. (2007). Conceptual bases of the correlation between the rights and obligations of the state and personality in the criminal process of the Russian Federation and their use for the legal regulation of activities on the distribution of the subject of criminal proceedings. Thesis of Doctoral Dissertation. Tomsk.

Bochkov, V.E., Kocherga, S.A., Martynova, T.N. (2007). Problems of Formation of Institutional and Legal Environment for Development of Distance Education in the Conditions of Education System Reform. Law and education, 8, 31-45.

Boyden, S. (1976). Conceptual Basis for the Study of the Ecology of Hu-man Settlements. Nature and Resources, XII(3), 6-12.

Chernogor, N.N. (2014). Legal Environment and its Methodological Significance for Legal Science and Practice. State Policy of Social and Humanities Education Reform: Comparison of the Experience of Post-Socialist States: Collection of Scientific Articles on the Materials of the International Scientific and Practical Seminar. Orenburg State University. Orenburg: Orenburg State University.

Convention for the Protection of Human Rights and Fundamental Freedoms. (1950). Available from: http://conventions.coe. int/Treaty/en/Treaties/Html/005.htm/ (Accessed on 08.08.2019)

Gavrilov, B.Ya. (2004). Legal Regulation of Protection of Constitutional Rights and Freedoms of Participants in Criminal Proceedings. Thesis of Doctoral Dissertation. Moscow.

International Covenant on Civil and Political Rights. (1996). General Assembly resolution 2200A (XXI). Available from: https:/www.ohchr.org/en/professionalinterest/pages/ccpr.aspx/ (Accessed on 28.08.2019)

Khorunzhiy, S.N. (2014). Doctrinal aspects of the legal environment: monographs. Voronezh: Publishing and Printing Center "Scientific Book".

Knox, J.H. (2008). Horizontal Human Rights Law. The American Journal of International Law, 102(1), 1-47.

Kutazova, I.V. (2011). Mechanism of criminal procedure provision of inadmissibility of disclosure of criminal proceedings data. Thesis of Doctoral Dissertation. Tyumen.

Lyngdorf, S., van der Wilt, H. (2009). Procedural Obligations Under the European Convention on Human Rights: Useful Guidelines for the Assessment of 'Unwillingness' and 'Inability' in the Context of the Complementarity Principle. International Criminal Law Review, 9(1), 39-75, DOI: https://doi.org/10.1163/157181209X398817.

Malko, A.V. (1994). Incentives and restrictions in law. Theoretical and informational aspect. Saratov: Saratov State University.

Mochalov, A.L. (2012). Constitution and constitutional justice as factors of formation of legal environment for modernization. Actual problems of the theory and practice of constitutional justice: Collection of scientific papers. Kazan: OffsetService LLC, VII, 347-353.

Odum, E.P. (1962). Relationship between Structure and Function in Eco-systems. Japanese Journal of Ecology, 12, 108-118. Platt, R. B. (1971). In: D.N. Lapedes, ed. Encyclopedia of Environmental Science, McGraw-Hill, Inc. New York.

Proshlyakov, A.D., Akhmatov, I.I. (2018). Concept, features and system of criminal procedure relations. Moscow. Jurlitinform. Saarinen, T.F. (1969). Perception of Environment. Association of American Geographers. Resource Paper No. 5.

Sigalov, K.E. (2008). The legal environment and legal properties of civil society. Law and education, 7, 134-142.

Smith, R.L. (1972). The Ecology of Man: An ecosystem approach. Harper and Row Publishers, New York.

Tourkochoriti, I. (2019). What Is the Best Way to Realise Rights? Oxford Journal of Legal Studies, 39(1), 209-228, DOI: https://doi.org/10.1093/ojls/gqz004

Universal Declaration of Human Rights. (1948). General Assembly resolution 217 A (III). Available from: http://www.un.org/ Overview/rights.html/ (Accessed on 18.08.2019)

Vavilin, E.V. (2009a). Favorable legal environment as the basis for the enforcement of civil rights. Materials of the international scientific-practical conference devoted to the 15th anniversary of the Constitution of the Russian Federation. Moscow.

Vavilin, E.V. (2009b). Favourable legal environment as a condition for the smooth exercise of rights and performance of duties. Russian Law Journal, 3(66), 61-66.

Volodina, L.M. (2003). Mechanism of Ensuring the Rights of the Person in the Russian-Russian Criminal Proceedings. Thesis of Doctoral Dissertation. Moscow.

Zhiltsov, N.A., Cherdakov, O.I., Chernogor, N.N., Minin, A.Y., Koval, A.V. (2013). The concept of innovative development of the legal environment. Moscow. International Law Institute. 